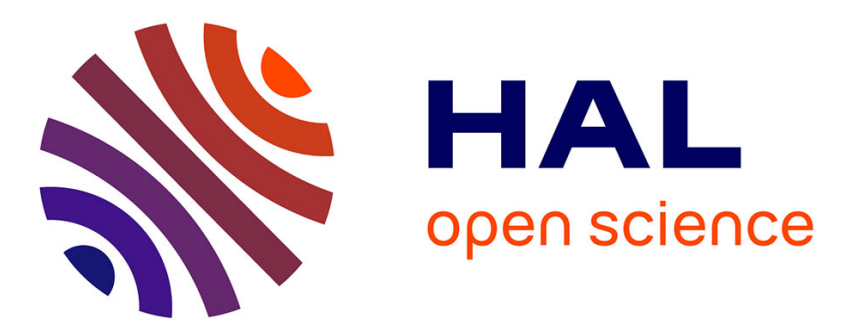

\title{
The oldest 'Megapodagrionidae' (Odonata, Zygoptera) discovered in the Lower Cretaceous Yixian Formation, China
}

\author{
Diying Huang, Dany Azar, André Nel
}

\section{- To cite this version:}

Diying Huang, Dany Azar, André Nel. The oldest 'Megapodagrionidae' (Odonata, Zygoptera) discovered in the Lower Cretaceous Yixian Formation, China. Cretaceous Research, 2017, 84, pp.426-430. 10.1016/j.cretres.2017.12.003 . hal-01668699

\section{HAL Id: hal-01668699 \\ https://hal.sorbonne-universite.fr/hal-01668699}

Submitted on 20 Dec 2017

HAL is a multi-disciplinary open access archive for the deposit and dissemination of scientific research documents, whether they are published or not. The documents may come from teaching and research institutions in France or abroad, or from public or private research centers.
L'archive ouverte pluridisciplinaire HAL, est destinée au dépôt et à la diffusion de documents scientifiques de niveau recherche, publiés ou non, émanant des établissements d'enseignement et de recherche français ou étrangers, des laboratoires publics ou privés. 
The oldest 'Megapodagrionidae' (Odonata, Zygoptera) discovered in the Lower Cretaceous Yixian Formation, China

Huang Diying ${ }^{\mathrm{a}, *}$, Azar Dany ${ }^{\mathrm{a}, \mathrm{b}}, \mathrm{Nel}$ Andrée,*

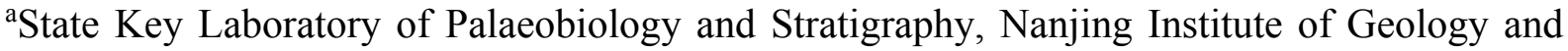
Palaeontology, Chinese Academy of Sciences, Nanjing, People's Republic of China.

${ }^{\mathrm{b}}$ Lebanese University, Faculty of Sciences II, Department of Biology, Beirut, Lebanon.

'Institut de Systématique, Évolution, Biodiversité, ISYEB - UMR 7205 - CNRS, MNHN, UPMC, EPHE, Muséum national d'Histoire naturelle, Sorbonne Universités, 57 rue Cuvier, CP 50, Entomologie, F-75005, Paris, France.

* Corresponding authors, e-mail: huangdiying@sina.com, anel@mnhn.fr

\section{ABSTRACT}

Cretapodagrion sibelleae gen. et sp. nov., oldest representative and first Mesozoic 'Megapodagrionidae', is described on the basis of a complete wing from the Lower Cretaceous of Yixian Formation (ca. 124.6 Ma) in China. It shows some similarities with the three extant genera of the 'Megapodagrioninae' and the enigmatic genus Mesopodagrion.

Keywords:

Insecta

Odonata

'Megapodagrionidae'

first appearance date 
gen. et sp. nov.

China

\section{Introduction}

The damselfly family 'Megapodagrionidae' is rather frequent and diverse in the Cenozoic, with ca. 20 species, ranging between the Paleocene and the Pliocene, exclusively from the Palaearctic and Nearctic regions (Azar and Nel, 2008; Zessin, 2011). This 'family' is nowadays restricted to warm, mainly intertropical, biotas. Nearly all the known fossil taxa are based on wing compressions in lacustrine sediments, while body fragments are rarely preserved. Dijkstra et al. (2014) demonstrated that the 'Megapodagrionidae' is a polyphyletic group. The 'megapodagrionid' Argiolestinae Fraser, 1957 is currently considered as a separate family Argiolestidae, but also without 'unequivocally unique character available for adults' (Kalkman and Theischinger, 2013). The 'megapodagrionid' Philosininae Ris, 1917 was also considered in its own family Philosinidae by Dijkstra et al. (2014) who restricted the Megapodagrionidae to the sole extant genera Allopodagrion Förster, 1910, Megapodagrion Selys, 1885, and Teinopodagrion De Marmels, 2001. There is no clear synapomorphy about wing venation that would characterize these families. Thus it is difficult to attribute the fossil 'megapodagrionids' to the families proposed by Dijkstra et al. (2014).

The distribution of the extant 'Megapodagrionidae' in all the intertropical areas suggests a great antiquity for these damselflies. Nevertheless they remain unknown in the Cretaceous, despite the recent progresses in our knowledge on the damselflies of this period (Zheng et al., 2016a-c, 2017a,b; Huang et al., 2017; etc.). Here we describe the first Cretaceous fossil attributable to the 'Megapodagrionidae', probably closely related to the Megapodagrionidae sensu stricto. 


\section{Material and methods}

Only one specimen with part and counterpart collected during 2015 at Sihetun locality (41 ${ }^{\circ} 37^{\prime}$ North, $120^{\circ} 50^{\prime}$ East), Beipiao City, Liaoning Province (Fig. 1). It is an isolated wing preserved in grayish finely laminated tuffaceous shale of a volcanic paleolake under warm climate (Jiang et al., 2012). It co-occurred with abundant Eosestheria. The Sihetun locality has yielded very rich animal fossils such as dinosaurs, birds, mammals, insects, conchostracans, ostracods, crustaceans, and bivalves. Isotopic dating indicates that the fossil rich layer is 124.6 Ma in age (Swisher III et al., 1999, 2001).

We follow the wing venation nomenclature of Nel et al. (1993) and Bechly (1996), modified from that of Riek and Kukalová-Peck (1984). Abbrevations for vein names are: AA analis anterior; Ax1 and Ax2 primary antenodal crossveins; IRx intercalary radial vein; MA median anterior; MP median posterior; $\mathrm{N}$ nodus; Pt pterostigma; RPx branches of radius posterior; $\mathrm{CuA}$ cubitus anterior; $\mathrm{CuP}$ cubitus posterior.

The ZooBank number for the genus Cretapodagrion is urn:1sid:zoobank.org:act:C3139CE3-13C6-4811-B006-7823AE86EDDB, and that for Cretapodagrion sibelleae is urn:lsid:zoobank.org:act:ED94AF25-0584-4F13-AC3E52DC9062B0FA.

\section{Systematic palaeontology}

Order Odonata Fabricius, 1793

Suborder Zygoptera Selys, 1854

Family Megapodagrionidae Calvert, 1913 (sensu lato)

Genus Cretapodagrion gen. nov.

Type species: Cretapodagrion sibelleae sp. nov.

Etymology. Named after the Cretaceous period and Podagrion. 
Diagnosis. Wing characters only: basal side of pterostigma and pterostigmal brace not oblique; postnodal area relatively short, with only 12 postnodal crossveins; a zigzagged long secondary longitudinal vein between IR1 and RP1; distal side of discoidal cell strongly oblique; $\mathrm{CuP}$ basad of base of $\mathrm{AA} ; \mathrm{MP}+\mathrm{Cu}$ apparently basally fused with anal vein (or at least strongly approximate; base of RP3/4 well basad of subnodus; base of IR2 below subnodus.

\section{Cretapodagrion sibelleae sp. nov.}

Fig. 2

Material: Holotype NIGP166620, stored at Nanjing Institute of Geology and Palaeontology, China.

Etymology. Named after Sibelle Azar, geologist and wife of ene of-Dany Azar, who has collected this specimen.

Locality and occurrence. Sihetun, Beipiao City, West Liaoning Province, NE China; Yixian Formation, Barremian-Aptian, Lower Cretaceous.

Diagnosis. As for the genus, wing hyaline, ca. $30 \mathrm{~mm}$ long.

Description. A complete wing, axillary sclerite and ScA visible; wing apparently hyaline, with pterostigma pale brown; wing $30.1 \mathrm{~mm}$ long, $5.8 \mathrm{~mm}$ wide, distance from base to arculus 6.5 $\mathrm{mm}$, from arculus to nodus $5.9 \mathrm{~mm}$, from nodus to pterostigma $12.7 \mathrm{~mm}$, from pterostigma to wing apex $3.9 \mathrm{~mm}$; from base to Ax1 $4.3 \mathrm{~mm}$, between Ax1 and Ax2 $2.1 \mathrm{~mm}$; pterostigma elongate and broad, $2.7 \mathrm{~mm}$ long, $0.9 \mathrm{~mm}$ wide, covering three cells; pterostigmal brace aligned with basal side of pterostigma, but very weakly oblique; distal side of pterostigma slightly more oblique than basal side, but anterior margin not distinctly longer than posterior one; no secondary antenodal crossvein; Ax2 aligned with arculus; 12 postnodal crossveins, nearly all aligned with the corresponding postsubnodals; one crossvein in antesubnodal space; subnodus and nodal brace weakly oblique; base of RP3/4 nearly midway between arculus and 
subnodus, at $2.5 \mathrm{~mm}$ from subnodus; base of IR2 below subnodus; base of RP2 four cells, 3.4 mm distal of subnodus; base of IR1 three cells, $2.4 \mathrm{~mm}$ distal of that of RP2; a zigzagged secondary longitudinal vein between IR1 and RP1, beginning four cells distal of base of IR1; a tendency to form pseudo-transverse veins in distal part of areas between IR2, RP3/4, MA and MP, caused by an alignment of row of cells; 1-2 rows of cells between IR1 and RP2, RP2 and IR2, IR2 and RP3/4, and RP3/4 and MA; distal end of MA zigzagged; a tendency to form only one row of cells in postdiscoidal area, also in area between MP and $\mathrm{CuA}$, and below $\mathrm{CuA}$; discoidal cell elongate and narrow, with basal side $0.3 \mathrm{~mm}$ long, anterior side $1.2 \mathrm{~mm}$ long, posterior side $1.9 \mathrm{~mm}$ long, and distal side $0.8 \mathrm{~mm}$ long, distal side strongly oblique, not parallel to basal side; petiole very long; $\mathrm{MP}+\mathrm{Cu}$ apparently fused to anal vein for a long distance in petiole, separating just basal of $\mathrm{Ax} 1$; $\mathrm{CuP}$ emerging from $\mathrm{MP}+\mathrm{Cu}$ just basal of base of AA; CuA very long, ending on posterior wing margin only at a level five cells basal of pterostigma.

\section{Discussion}

Cretapodagrion gen. nov. can be attributed to the Coenagrionomorpha Bechly, 1996 on the basis of the following characters (Bechly, 1996, 2016): pterostigma shortened, compared to those of the clade Calopterygida Bechly, 1996 (in the ground plan, the pterostigma being reduced in many Calopterygidae); postnodal and postsubnodal crossveins aligned; lestine oblique vein absent; tendency towards the formation of pseudo-transverse veins in distal part of wing, caused by an alignment of rows of crossveins. Within the Coenagrionomorpha, the Hypolestidae Tillyard \& Fraser, 1938 are excluded because of the positions of the bases of RP3/4 and IR2, and shape of distal parts of main veins, not distinctly curved apically. The Coenagrioniformia Bechly, 1996 are also excluded because Cretapodagrion has intercalary longitudinal veins between main veins, a relatively long 
pterostigma, postnodal and postsubnodal crossveins not aligned with the crossveins immediately below them.

Cretapodagrion shows some similarities with the extant 'Megapodagrionidae' sensu stricto sensu Dijkstra et al. (2014), viz. a relatively long and broad pterostigma, a basal side of pterostigma and a pterostigmal brace not oblique, RP1 not making an angle, presence of intercalary longitudinal veins between main veins, base of IR2 aligned with subnodus while that of RP3/4 is distinctly basal with an elongate cell between them, long discoidal cell with distal side very oblique, distal part of MA long and zigzagged, very long $\mathrm{CuA}$ and MP (Bechly, 1996). Cretapodagrion differs from these extant genera in the CuP basal of base of AA, and the presence of a long intercalary longitudinal vein between IR1 and RP1 (Münz, 1919; Garrison et al., 2010).

Nevertheless, due to the relative confusion in the current 'megapodagrionid' classification, we compare Cretapodagrion to all the other 'megapodagrionid' genera. One possible difference between Cretapodagrion and all the extant and other fossil 'Megapodagrionidae' is the apparent basal fusion of $\mathrm{MP}+\mathrm{Cu}$ with the anal vein in the petiole, but in some extant taxa, $\mathrm{MP}+\mathrm{Cu}$ is so close to the anal vein that they could appear fused, so it is also possible in the fossil (Garrison et al., 2010).

All the extant Neotropical 'Megapodagrionidae' have no intercalary longitudinal vein between IR1 and RP1, unlike Cretapodagrion (Garrison et al., 2010).

Also within the extant Argiolestidae, Amanipodagrion Pinhey, 1962 has the distal side of discoidal cell not oblique (Pinhey, 1962). The genera Celebargiolestes Kennedy, 1925, Allolestes Kennedy, 1925, Austroargiolestes Kennedy, 1925, Caledargiolestes Kennedy, 1925; Archaeopodagrion Kennedy, 1939, Burmargiolestes Kennedy, 1925, Bornargiolestes Kimmins, 1936 (both among the closest relatives of Thaumatoneuridae, after Dijkstra et al., 2014), Dimeragrion Calvert, 1913 (not related to Argiolestidae after Dijkstra et al., 2014), 
Heteragrion Selys, 1862, Podopteryx Selys, 1871, and Argiolestes Selys, 1862 have the base of RP3/4 below subnodus (Münz, 1919; Kennedy, 1925, 1939; Kalkman and Theischinger, 2013; Dow, 2014). Agnophilogenia Kennedy, 1941, Caledopteryx Kennedy, 1925, Dimeragrion Calvert, 1913, Heteragrion Selys, 1862, Nesolestes Selys, 1891, Trineuragrion Ris, 1915, Paraphlebia Selys in Hagen, 1861, Neurolestes Selys, 1882, Mesagrion Selys, 1885, Heteropodagrion Selys, 1885, Neuragrion Karsch, 1891, Protolestes Förster, 1899 (not related to Argiolestidae after Dijkstra et al., 2014), Rhinagrion Calvert, 1913, Philogenia Selys, 1862, Wahnesia Förster, 1900, Sciotropis Rácenis, 1959, and Agriomorpha May, 1933 have a very long postnodal area, with a basal side of pterostigma very oblique (Förster, 1900; May, 1933; Kennedy, 1941; Winstanley and Davies, 1982; Garrison et al., 2010). Podolestes Selys, 1862 have a distal side of discoidal cell not oblique (Fraser, 1926). Calilestes Fraser, 1926 has a different pattern of branches of CuA (Fraser, 1926). Miniargiolestes Theischinger, 1998 and Griseargiolestes Theischinger, 1998 has the base of AA opposite or well distal of arculus (Theischinger, 1998).

Tatocnemis Kirby, 1889 (treated under the name Nesocnemis Selys, 1891, in Münz, 1919) has veins RP3/4 and IR2 arising distal of the subnodus and very oblique basal side of pterostigma.

Within the Philosinidae, Cretapodagrion differs from Philosina Ris, 1917 in the relative positions of subnodus and bases of RP2 and IR2. Rhinagrion Calvert, 1913 has a very long postnodal area, with a basal side of pterostigma very oblique.

Mesopodagrion McLachlan, 1896, a taxon of uncertain position (Dijkstra et al., 2014), greatly resembles Cretapodagrion, but it differs from Cretapodagrion in the rather more oblique pterostigmal brace, absence of the intercalary longitudinal vein between IR1 and RP1, and longer postnodal area with much more postnodal crossveins (Yu and $\mathrm{Bu}, 2009)$. 
Cretapodagrion is clearly different from all the fossil taxa currently attributed to the 'Megapodagrionidae': Eopodagrion Cockerell, 1921 (Lowermost Oligocene of Florissant, U.S.A.) has a short pterostigma covering no more than two cells (Cockerell, 1921). Thanetophilosina Nel et al., 1997 (Paleocene, Menat, France) has much more postnodal crossveins, CuP distal of base of AA, and a broader discoidal cell (Nel et al., 1997). Melanagrion Cockerell, 1907 (Lowermost Oligocene of Florissant, U.S.A.) has two rows of cells in the cubito-anal area and in area between C and RA distad of pterostigma (Cockerell, 1907). Miopodagrion Kennedy, 1925 (Lowermost Oligocene of Florissant, U.S.A.) has two rows of cells between C and RA distad of pterostigma (Kennedy, 1925). Vulcagrion Nel \& Paicheler, 1994 (Miocene-Pliocene of central France has veins IR2 and RP3/4 fused basally distad of subnodus (Nel et al., 1996). Eckfeldia Petrulevičius et al., 2008 and Furagrion Petrulevičius et al., 2008 (Paleocene - Eocene of Denmark) have a distinctly oblique basal side of pterostigma and a very long postnodal space (Petrulevičius et al., 2008). Morsagrion Zessin, 2011 (Paleocene - Eocene of Denmark) has a less oblique basal side of pterostigma, but a postnodal space longer than in Cretapodagrion and no intercalary longitudinal vein between RP1 and IR1 (Zessin, 2011). Hanklitia Zessin, 2011 (Paleocene - Eocene of Denmark, based on the basal third of a wing) differs from Cretapodagrion in the more distal position of $\mathrm{CuP}$, distal of base of AA (Zessin, 2011). Cerdanyagrion Nel et al., 1996 (Upper Miocene, Spain) shares with Cretapodagrion the presence of a long intercalary longitudinal vein between RP1 and IR1 but it has a distinctly oblique basal side of pterostigma (Nel et al., 1996). Oligoargiolestes Kennedy, 1925 (Latest Eocene of UK) differs from Cretapodagrion in the absence of an intercalary longitudinal vein between RP1 and IR1 and the oblique basal side of pterostigma (Nel and Fleck, 2014). Lithagrion Scudder, 1890 (Early Oligocene, USA; Early Miocene, Kazakhstan) shares with Cretapodagrion similar pterostigma and a relatively broad area between IR1 and RP1, but it has a postnodal area longer than in Cretapodagrion 
and no intercalary longitudinal vein between RP1 and IR1 (Scudder, 1890; Martynov, 1929). Electropodagrion Azar and Nel, 2008 (Eocene Baltic amber) shares with Cretapodagrion a relatively short postnodal area, but it differs from Cretapodagrion in the absence of an intercalary longitudinal vein between RP1 and IR1 (Azar and Nel, 2008).

\section{Concluding remarks}

Cretapodagrion shows similarities with the three extant genera of Megapodagrionidae sensu stricto but also with Mesopodagrion. Thus we provisionally attribute this new genus and species to the 'Megapodagrionidae' sensu lato because, after the study of Dijkstra et al. (2014), the venation seems to be not sufficient to define the phylogenetic relationships within the 'Megapodagrionidae' sensu lato. Further discoveries of new specimens showing the body structures and especially the genitalia, will help to solve the position of Cretapodagrion. Nevertheless the discovery in the Lower Cretaceous of China of a taxon attributable to the 'Megapodagrionidae' strongly suggests the antiquity of these damselflies, formerly only known in the Cenozoic.

\section{Acknowledgements}

We sincerely thank two anonymous referees for their very useful comments on the first version of the paper. We are grateful to Jie Sun for his assistance in making the figures. Financial support was provided by the Ministry of Science and Technology (2016YFC0600406), the Strategic Priority Research Program of the Chinese Academy of Sciences (XDB18000000, XDPB05), and the National Natural Science Foundation of China (91514302). This study is a contribution to UNESCO-IUGS IGCP Project 632.

\section{References}


Azar, D., Nel, A., 2008. First Baltic amber megapodagrionid damselfly (Odonata: Zygoptera). Annales de la Société Entomologique de France (N.S.) 44, 451-457.

Bechly, G., 1996. Morphologische Untersuchungen am Flügelgeäder der rezenten Libellen und deren Stammgruppenvertreter (Insecta; Pterygota; Odonata), unter besonderer Berücksichtigung der Phylogenetischen Systematik und des Grundplanes der *Odonata. Petalura Special Volume 2, 402 pp.

Bechly, G., 2016. Phylogenetic systematics of Odonata. homepage on the Internet: https://bechly.lima-city.de/phylosys.htm

Cockerell, T.D.A., 1907. Fossil dragonflies from Florissant. Bulletin of the American Museum of Natural History 23, 133-139.

Cockerell, T.D.A., 1921. Eocene insects from the Rocky Mountains. Proceedings of the United States National Museum 57, 233-260.

Dijkstra, K.-D.B., Kalkman, V.J., Dow, R.A., Stokvis, F.R., Van Tol, J., 2014. Redefining the damselfly families: a comprehensive molecular phylogeny of Zygoptera (Odonata). Systematic Entomology 39, 68-96.

Dow, R.A., 2014. A review of the genus Bornargiolestes Kimmins, 1936 (Odonata: Zygoptera) with a description of two new species from Sarawak, Malaysia. Journal of Threatened Taxa 6, 5700-5711.

Fraser, F.C., 1926. Notes on a collection of dragonflies (Odonata) from the Dutch East Indies and descriptions of four new species from the neighbouring continent. Treubia 8, 467-494.

Förster, F., 1900. Odonaten aus Neu-Guinea. 2. Természetrajzi Füzetek kiadja a Magyar nemzeti Muzeum 23, 81-108.

Garrison, R.W., von Ellenrieder, N., Louton, J.A., 2010. Damselfly genera of the New World. An illustrated and annotated key to the Zygoptera. The John Hopkins University Press, Baltimore, xiv +490 pp. 
Huang, Diying, Azar, D., Cai, Chenyang, Maksoud, S., Nel, A., Bechly, G., 2017. Mesomegaloprepidae, a remarkable new damselfly family (Odonata: Zygoptera) from midCretaceous Burmese amber. Cretaceous Research 73, 1-13.

Jiang, Baoyu, Fürsich, F.T. and Hethke, M. 2012. Depositional evolution of the Early Cretaceous Sihetun Lake and implications for regional climatic and volcanic history in western Liaoning, NE China. Sedimentary Geology 257-260, 31-44.

Kalkman, V.J., Theischinger, G., 2013. Generic revision of the Argiolestidae (Odonata), with four new genera. International Journal of Odonatology 16, 1-52.

Kennedy, C.H., 1925. New genera of Megapodagrioninae, with notes on the subfamily. Bulletin of the Museum of Comparative Zoology 67, 291-311.

Kennedy, C.H., 1939. Archaeopodagrion bicorne, a very primitive dragonfly from Eastern Ecuador (Odonata: Megapodagrioninae). Annals of the Entomological Society of America 32, $32-43$.

Kennedy, C.H., 1941. Agnophilogenia monotis, new genus and species of dragonfly from humid Northwestern Ecuador (Odonata: Megapodagrionidae). Annals of the Entomological Society of America 34, 490-494.

Martynov, A.V., 1929. Fossil insects from Tertiary deposits in Ashutas Saisan district. Trudy Geologicheskogo Muzeya Akademii nauk SSSR 5, 173-216.

May, E., 1933. Zwei neue Genera der Legion Podagrion (Agriomorpha und Lestomima). Senckenbergiana $15,340-345$.

Münz, P.A., 1919. A venational study of the suborder Zygoptera (Odonata) with keys for the identification of genera. Memoirs of the Entomological Society (of the Academy of Natural Sciences) 3, 1-78. 
Nel, A., Arillo, A., Martínez-Delclòs, X., 1996. New fossil Odonata (Insecta) from the Upper Miocene of France and Spain. (Anisoptera and Zygoptera). Neues Jahrbuch für Geologie und Paläontologie, Abhandlungen 199, 167-219.

Nel, A., Fleck, G., 2014. Dragonflies and damselflies (Insecta: Odonata) from the Late Eocene of the Isle of Wight. Earth and Environmental Science, Transactions of the Royal Society of Edinburgh 104, 283-306.

Nel, A., Martínez-Delclòs, X., Paicheler, J.-C., Henrotay, M., 1993. Les 'Anisozygoptera' fossiles. Phylogénie et classification (Odonata). Martinia Numéro Hors Série 3, 1-311.

Nel, A., Martínez-Delclòs, X., Papier, F., Oudard, J., 1997. New Tertiary fossil Odonata from France. (Sieblosiidae, Lestidae, Coenagrioniidae, Megapodagrionidae, Libellulidae). Deutsche Entomologische Zeitschrift 44, 231-258.

Petrulevičius, J.F., Wappler, T., Wedmann, S., Rust, J., Nel, A., 2008. New megapodagrionid damselflies (Odonata: Zygoptera) from the Paleogene of Europe. Journal of Paleontology 82, $1173-1181$.

Pinhey, E., 1962. Some records of Odonata collected in Tropical Africa. Journal of the Entomological Society of Southern Africa 25, 20-50.

Riek, E.F., Kukalová-Peck, J., 1984. A new interpretation of dragonfly wing venation based upon Early Carboniferous fossils from Argentina (Insecta: Odonatoidea) and basic characters states in pterygote wings. Canadian Journal of Zoology 62, 1150-1166.

Scudder, S.H., 1890. The fossil insects of North America (with notes on some European species). 2. The Tertiary insects. Report of the United States Geological Survey of the Territories 13, 1-734.

Swisher III, C.C., Wang, Y.Q., Wang, X.L., Xu, X., Wang, Y., 1999. Cretaceous age for the feathered dinosaurs of Liaoning, China. Nature 400, 58-61. 
Swisher III, C.C., Wang, X.L., Zhou, Z., Wang, Y., Jin, F., Zhang, J., Xu, X., Zhang, F., Wang, Y., 2001. Further support for a Cretaceous age for the feathered-dinosaur beds of Liaoning, China: new 40Ar/39Ar dating of the Yixian and Tuchengzi formations. Chinese Science Bulletin 47, 135-138.

Theischinger, G., 1998. A new species of Griseargiolestes Theischinger from Australia (Odonata: Zygoptera: Megapodagrionidae). Stapfia 55, 623-627.

Winstanley, W.J., Davies, D.A.L., 1982. Caledopteryx maculata spec. nov., from New Caledonia (Odonata: Megapodagrionidae). Odonatologica 11, 339-346.

Yu, X., Bu, W., 2009. A revision of Mesopodagrion McLachlan, 1896 (Odonata: Zygoptera: Megapodagrionidae). Zootaxa 2202, 59-68.

Zessin, W., 2011. Neue Insekten aus dem Moler (Palaeozaen/Eozaen) von Daenemark Teil 1 (Odonata: Epallagidae, Megapodagrioniidae). Virgo, Mitteilungsblatt des Entomologischen Vereins Mecklenburg 14, 62-71.

Zheng, D., Zhang, Q., Chang, S.C., Wang, B., 2016a. A new damselfly (Odonata: Zygoptera: Platystictidae) from mid-Cretaceous Burmese amber. Cretaceous Research 63, 142-147.

Zheng, Daran, Wang, Bo, Jarzembowski, E.A., Chang, Su-Chin, Nel, A., 2016b. The first fossil Perilestidae (Odonata: Zygoptera) from mid-Cretaceous Burmese amber. Cretaceous Research 65, 199-205.

Zheng, Daran, Wang, Bo, Jarzembowski, E.A., Chang, Su-Chin, Nel, A., 2016c. Burmadysagrioninae, a new subfamily (Odonata: Zygoptera: Dysagrionidae) from midCretaceous Burmese amber, Cretaceous Research 67, 126-132.

Zheng, Daran, Zhang, Qingqing, Nel, A., Jarzembowski, E.A., Zhou Z., Chang, Su-Chin, Wang, Bo, 2017a. New damselflies (Odonata: Zygoptera: Hemiphlebiidae, Dysagrionidae) from mid-Cretaceous Burmese amber. Alcheringa 41, 12-21. 
Zheng, Daran, Nel, A., Jarzembowski, E.A., Chang, Su-Chin, Zhang, Haichun, Xia, Fangyuan, Liu, Haoying, Wang, Bo, 2017b. Extreme adaptations for probable visual courtship behaviour in a Cretaceous dancing damselfly. Nature Scientific Reports, 7, 1-8.

Fig. 1. A, Chinese map with location of Liaoning Province; B, Map of Liaoning Province with location of Sihetun fossil locality (indicated by a bug); C, Shales of Yixian Formation where the material was collected.

Fig. 2. Cretapodagrion sibelleae gen. et sp. nov., holotype. a, photograph; b, drawing. Scale bars $=5 \mathrm{~mm}$ 
